\title{
Persepsi Stakeholder terhadap Kurikulum Berbasis Kompetensi Politeknik Pariwisata Makassar (Studi pada Industri Perhotelan Kota Makassar)
}

\author{
Wim Johannes Winowatan \\ Tourism Polytecnic State of Makassar, Indonesia \\ Email: winossjoss@yahoo.com
}

(Diterima: 17-Juli-2018; di revisi: 14-Agustus-2018; dipublikasikan: 30-Desember-2018)

\begin{abstract}
ABSTRAK
Fokus penelitian ini adalah mengetahui keefektifan implementasi Kurikulum Berbasis Kompetensi Politekpar Makassar pada Industri perhotelan. Pendekatan Kualitatif presfektif studi kasus digunakan untuk mengungkap persepsi stakeholder tentang penerapan Kurikulum Berbasis Kompetensi (KBK) yang digunakan di Politeknik Pariwisata Makassar. Secara Metodologis, data diperoleh melalui 1) Dokumentasi, 2) Wawancara mendalam ( indepht interview), dan 3) Studi Pustaka. Key Informan merupakan stakeholder yang memiliki hubungan langsung dengan industri perhotelan. Diantaranya: General Manajer Jolin hotel, Vape Hotel, Sous Chef Four Point Hotel, Guru SMK Pariwisata dan wirausaha kuliner. Pengumpulan data dengan observasi partisipan dan wawancara mendalam. Data disusun secara kategorisasi dan kronologis, diperiksa dan di-koding secara terus menerus. Strategi verifikasi data dengan menerapkan Trianggulation, Member Checking dan Audit Trail. Hasil penelitian menunjukkan bahwa kurikulum berbasis kompetensi sudah relevan dengan kebutuhan industry, sebab kurikulum yang digunakan sinergi dengan system dan prosedur kerja pada industry. Akan tetapi, untuk memaksimalkan relevansi antara industry dan kompetensi profesi maka perlu penguatan terhadap mata kuliah pendalaman profesi, caranya dengan memperbanyak praktikum pada mata kuliah profesi yang diperlukan sesuai dengan perkembangan masyarakat modern.
\end{abstract}

Kata Kunci: Stakeholder, KBK

ABSTRACT

The focus of this study is to study the effectiveness of the implementation of the Makassar Polytechnic Competency-Based Curriculum in the hospitality industry. Qualitative studies used in case studies were used to reveal stakeholder perceptions about the application of the Competency-Based Curriculum (KBK) used at the Makassar Tourism Polytechnic. Methodologically, data is obtained through 1) Documentation, 2) In-depth interviews (in-depth interviews), and 3) Library Studies. Key informants are stakeholders who have a direct relationship with the hospitality industry. Among them: General Manager Hotel Jolin, Hotel Vape, Sous Chef Four Point Hotel, Vocational Teacher of Tourism and culinary entrepreneurship. Data collection by gathering participation and in-depth interviews. Data are arranged categorically and chronologically, completed and continuously coded. Strategy to verify data by agreeing to Triangulation, Member Checking and Audit Trail.The results of the study show that the competencybased curriculum is relevant to the needs of the industry, because the curriculum is used in synergy with work systems and procedures in the industry. However, to maximize the relevance between industry and professional competency, it is necessary to increase the professions deepening courses, improve by increasing practicum in professional subjects needed in accordance with the development of modern society.

Keywords: Stakeholders, KBK

Copyright (C) 2018 Universitas Negeri Makassar. This is an open access article under the CC BY license (http://creativecommons.org/licenses/by/4.0/) 


\author{
124 Jurnal Administrare: Jurnal Pemikiran Ilmiah dan Pendidikan Administrasi Perkantoran \\ Vol. 5, No. 2, Juli - Desember 2018, Hal 123-128
}

\title{
PENDAHULUAN
}

Dari teoritis hingga praktisi administrasi publik di negara berkembang memiliki berbagai kelemahan birokrasi tradisional, misalnya inefiensi, produktivitas rendah, kurang mampu melaksanakan tugas pembangunan, korup, dan sebagainya (Boehmer-Christiansen, 2002; Colenbrander \& Bavinck, 2017; Lane \& Ross, 1994; Yanguas \& Hulme, 2015). Salah satu hambatan terbesar dalam pembangunan di negara berkembang, termasuk Indonesia, adalah sistem administrasi publik yang belum memiliki sumberdaya manusia yang cukup untuk melaksanakan berbagai kegiatan pembangunan yang semakin nyata.

Dengan demikian, peran pemerintah menjadi sangat penting. Arah pembangunan memerlukan perubahan fungsi pemerintah dari "pelaku utama" menjadi "fasilitator". Untuk itu diperlukan suatu sistem administrasi publik yang berbeda dengan sistem yang kita anut selama ini. Maka, merekomendasikan struktur yang lebih "organis adaptif", simplifikasi prosedur memiliki orientasi produktivitas dan pelayanan publik, serta lingkungan (pendidikan-politikbirokratik) yang mampu memberikan pengawasan yang efektif (Adams \& Klobodu, 2017; Ongolo, 2015; Osipian, 2017; Schlosser, 2017; Zakharova, Liga, \& Sergeev, 2015). Salah satu sector yang berorientasi pada produktivitas dan pelayanan public adalah pariwisata.

Pariwisata sebagai sektor utama pembangunan di Indonesia. Pariwisata yang diakui sebagai sumber pendapatan devisa terbesar kedua di Indonesia setelah Migas (Kemenpar, 2017). Bahkan laporan resmi World Economis Forum, Indonesia melalui Branding Wonderfull Indonesia, melejit delapan peringkat hingga ke posisi-42 pada 2017. Pariwisata merupakan komoditas yang paling berkelanjutan hingga ke level bawah masyarakat, menyentuh segala aspek. Namun demikian, seiring melejitnya pariwisata di kawasan Asia Pasifik ternyata juga dibarengi dengan fenomena globaliasasi. Alan Schoot dalam The Limits of Globalization: Cases and Argument (dalam Yasraf Piliang). Menerangkan bahwa "Globalisasi adalah kontradiksi antara global dan lokal". Artinya bahwa, kehadiran teknologi informasi dan teknologi komunikasi mempercepat akselerasi proses globalisasi. Dengan kata lain, percepatan teknologi global apabila tidak diimbangi dengan peningkatan kompetensi manusia Indonesia, maka dipastikan kita akan menjadi penonton di negeri sendiri.

Globalisasi dapat menciptakan berbagai tantangan dan permasalahan yang baru dan harus dijawab, dipecahkan dalam upaya memanfaatkan potensi sumber daya alam dan sumber daya manusia. Salah satu permasalahan mendasar bangsa ini adalah kualitas sumber daya manusia yang sangat mengkhawatirkan, laporan terbaru world Competetitiveness Yearbook tahun 2009 tentang daya saing bahwa Indonesia menempati peringkat ke-42. Angka ini sebenarnya meningkat dibanding tahun sebelumnya yang membuat Indonesia masih berada di posisi 51 . Meski demikian, peringkat daya saing Indonesia tersebut masih tertinggal dibanding Negara Asia Tenggara lain seperti Singapura, Malaysia dan Thailand. Singapura menempati posisi ketiga, sedangkan Malaysia berada di peringkat ke-18, dan Thailand berada di urutan 26.

Klimaks dari permasalahan ini semakin mencuat dari dunia usaha atau industry. Laporan Depdiknas tahun 2002 menemukan sejumlah keluhan dari dunia usaha bahwa lulusan yang memasuki dunia kerja belum memiliki kesiapan kerja yang baik. Sistem pendidikan yang selama ini diterapkan dirasakan belum mampu menghasilkan kualitas sumberdaya manusia yang mampu bersaing di pasar bebas, serta kurang mendukung tuntutan dunia usaha dan industri akan kebutuhan tenaga kerja. 
Wim Johannes Winowatan; Persepsi Stakeholder terhadap Kurikulum... 125

Kementerian Pariwisata telah mencanangkan untuk fokus terhadap pengembangan kompetensi pada bidang pendidikan dan latihan pariwisata. Bahwa untuk meningkatkan standar kompetensi lulusan yang berdaya saing di pasar kerja nasional dan internasional, telah ditetapkan Peraturan Menteri Kebudayaan dan Pariwisata Nomor PM.48/ DL.107/MKP/2010 tentang Kurikulum Berbasis Kompetensi (KBK) Program Diploma pada Pendidikan Tinggi Pariwisata di Lingkungan Kementerian Kebudayaan dan Pariwisata. Dengan penerapan kurikulum tersebut diharapkan pembelajaran di perguruan tinggi lebih menitikberatkan pada sentuhan softskill mahasiswa.

Penelitian yang dilakukan Winowatan, W.J tahun 2018 tentang Implementasi Kebijakan Kurikulum Berbasis Kompetensi Terhadap Kebutuhan Industri yang dilakukan di Hotel Fave Daeng Tompo Makassar, Hotel JL Star Makassar dan Hotel Dalton Makassar membuktikan bahwa Kurikulum yang diterapkan di Politeknik Pariwisata Makassar masih relevan dengan kebutuhan terhadap industry khususnya tenaga kerja yang siap pakai. Hal ini pengakuan sejumlah Stakeholder masing-masing hotel bahwa implementasi kebijakan kurikulum Berbasis Kompetensi yang diterapkan di Politeknik Pariwisata Makassar berjalan dengan baik sesuai dengan capaian pembelajaran. Hal ini telah dibuktikan dengan adanya kesiapan mahasiswa dan luaran (out put) siap untuk bekerja dan, mampu menyesuaikan kondisi kerja pada industry.

Sebuah penelitian tentang Pengembangan Kurikulum Berbasis Kompetensi di Perguruan Tinggi (studi kasus penerapan kurikulum KBK di Politeknik Negeri Malang) mengemukakan bahwa dunia industry mendapatkan tenaga kerja terampil dengan benefit rendah, mengurangi waktu induction karyawan sehingga menurunkan cost perusahaan sementara kampus diuntungkan dengan terjalinya kerja sama dengan industry.

Polteknik Pariwisata Negeri Pariwisata Makassar sebagai salah satu perguruan tinggi dibawah Kementerian Pariwisata Republik Indonesia mempunyai tugas pokok melaksanakan pendidikan di atas tingkat pendidikan menengah pada jalur pendidikan profesional program diploma yang ditujukan pada keahlian dan keterampilan di bidang Kepariwisataan. Sejak tahun 2005 telah menggunakan kurikulum yang berbasis pada kompetensi hingga saat ini. Berdasarkan latar belakang di atas, penulis tertarik untuk mengevaluasi kurikulum dalam kaitannya pengaruh kurikulum terhadap lulusan. Dengan demikian, penulis berfokus pada persepsi stakeholder pengelolah Industri perhotelan terkait efektivitas penerapan kurikulum berbasis kompetensi di Politeknik Pariwisata Negeri Makassar.

\section{METODE}

Kajian ini menggunakan pendekatan deskriptif-kualitatif. Subjek dalam kajian ini adalah General Manajer Jolin hotel, Vape Hotel, Sous Chef Four Point Hotel, Guru SMK Pariwisata dan wirausaha kuliner. Data dikumpulkan melalui pengamatan dokumentasi, angket, dan wawancara. Dengan ini peneliti menemukan teori yang berasal dari data, memahami persepsi para stakeholder tentang implementasi kurikulum berbasis kompetensi di Politeknik Pariwisata Negeri Makassar. Obeservasi memungkinkan peneliti mencatat peristiwa dalam situasi yang berkaitan dengan pengetahuan proposional maupun pengetahuan yang langsung diperoleh dari data (Guba dan Linclon, 1981 dalam Moleong, 2007). Wawancara mendalam dilakukan secara terstruktur dan terbuka yang dirancang untuk memunculkan pandangan dan opini para 

126 Jurnal Administrare: Jurnal Pemikiran Ilmiah dan Pendidikan Administrasi Perkantoran Vol. 5, No. 2, Juli - Desember 2018, Hal 123-128

partisipan (Creswell, 2014). Data yang telah terkumpul diolah dan dianalisis dengan menggunakan analisis deskriptif data dengan menerapkan Trianggulation, Member Checking dan Audit Trail (Moleong, 2007).

\section{HASIL PENELITIAN DAN PEMBAHASAN}

\section{Hasil Penelitian}

Pengembangan Proses Pembelajaran yang dinginkan Kurikulum Berbasis Kompetensi, bukan menumpuk pada ilmu pengetahuan tetapi proses perubahan perilaku melalui pengalaman belajar dan diharapkan terjadi pengembangan berbagai aspek pada setiap peserta didik. Pengajar (guru) atau dosen bertugas mengelola pembelajaran baik dalam pengembangan strategi pembelajarn maupun menggunakan berbagai sumber belajar. Dengan demikian, proses pembelajaran tidak hanya diarahkan agar peserta didik mampu menguasai materi pembelajaran tetapi lebih diarahkan pada penguasaan kompetensi sesuai kurukulum.

Hal ini menjadi bukti bahwa, keterlibatan pihak industry atau stakeholder dalam menyusun, mengkonsep, dan memberikan masukan pada setiap kegiatan re-evaluasi kurikulum berbasis kompetensi adalah sudah tepat. Sebab, pada setiap kegiatan re-evaluasi Kurikulum Berbasis Kompetensi, pihak industri dilibatkan dan terlibat duduk bersama dalam rangka pencapaian tujuan utama dari Kurikulum Berbasis Kompetensi

Berdasarkan wawancara di lapangan, peneliti menemukan hubungan kausalitas antartema yang sejalan dengan fokus penelitian. Selanjutnya memahami berbagai istilah khusus/khas/asli tentangb persepsi implementasi kurikulum berbasis kompetensi di lingkungan Politeknik Pariwisata Negeri Makassar.

\section{Relevansi Kurikulum berbasis kompetensi di lingkungan Politeknik Pariwisata Negeri Makassar}

Wawancara dilakukan pada tanggal , 3 dan 5 Oktober2017 di Kampus Politeknik Pariwisata Negeri Makassar pukul 12.30 - 15.30. Pertanyaan diarahkan untuk mengetahui seperti apa persepsi para stakeholder dalam implementasi kurikulum berbasis kompetensi. Kedua narasumber merupakan pengampuh dan pengajar mata kuliah vokasional Program Studi Manajemen Tata Hidangan, teori maupun praktik.

Berdasarkan kesimpulan dari hasil wawancara menjelaskan bahwa Kebijakan kurikulum berbasis kompetensi pada Politeknik Pariwisata Makassar relevan dengan kebutuhan mahasiswa dan Namun demikian, meskipun masih relevan, perlu dipertimbangkan untuk membangun satu lintas komunikasi yang baik untuk penyampaian informasi, dengan peningkatan dan penambahan tenaga pengajar di lingkup Politeknik Pariwisata Makassar.

\section{Relevansi Kurikulum Berbasis Kompetensi Politekpar Negeri Makassar dengan kebutuhan industri}

Wawancara dilakukan pada tanggal , 14 dan 28 Oktober2017 di lokasi masing-masing partisipan. Pertanyaan diarahkan untuk mengetahui seperti apa persepsi para stakeholder dalam 
implementasi kurikulum berbasis kompetensi. Berdasarkan hasil wawancara menjelaskan bahwa Implemetasinya kebijakan kurikulum berbasis kompetensi di Politeknik Pariwisata Makassar secara umum, dapat berjalan dengan baik sesuai capaian pembelajaran dan tujuan organisasi dan sudah relevan dengan kebutuhan industri. Namun belum dapat dikatakan maksimal karena adanya kendala atau penghambat. Diantaranya, tidak terjalinnya komunikasi dalam penyampaian informasi dan koordinasi antara pemenrintah sebagai implementor terhadap industri. Salah satu faktor yang pendukung bagi keberhasilan suatu kebijakan yang telah ditetapkan adalah dengan adanya komunikasi.

\section{Pembahasan}

Implementasi Kebijakan Kurikulum Berbasis Kompetensi Terhadap Kebutuhan Industri relevan dengan kebutuhan tenaga kerja khususnya Output atau luaran yang dihasilkan oleh Politeknik Pariwisata Makassar. Sistem dan mekanisme serta prosedur kerja pada industri dengan kurikulum yang digunakan adalah sama. Namun demikian, masih terdapat kelemahan yang dilakukan dalam proses pembelajaran pada Politeknik Pariwisata Makassar yaitu, secara umum dalam pelaksanaan proses belajar mengajar masih menggunakan sistem praktikum secara manual sehingga berdampak pada industri yang sudah melakukan perubahan dengan mengikuti perkembangan pengetahuan dan teknologi. Demikian pula, didalam menetapkan kebijakan, tidak melibatkan industri dan tidak adanya komunikasi sehingga koordinasi dan informasi ke industri tidak maksimal. Komukasi yang baik dan adanya keterlibatan industri untuk duduk bersama dalam menetapkan kebijakan sangatlah penting sebab, industri adalah pengguna terhadap kebutuhan sumber daya manusia yang siap kerja sehingga tidak memerlukan waktu yang lama dalam proses rekruitment tenaga kerja yang dihasilkan oleh Politeknik Pariwisata Makassar.

\section{SIMPULAN}

Relevansi Kurikulum berbasis kompetensi di lingkungan Politeknik Pariwisata Negeri Makassar relevan dengan kebutuhan mahasiswa. Demikian halnya dengan kebutuhan industri. oleh karena itu, perlu penguatan terhadap mata kuliah pendalaman profesi, caranya dengan memperbanyak praktikum pada mata kuliah profesi yang diperlukan sesuai dengan perkembangan masyarakat modern. kurikulum berbasis kompetensi tentunya menjadi spektrum yang mampu mengurangi pengangguran di Indonesia.

\section{DAFTAR PUSTAKA}

Adams, S., \& Klobodu, E. K. M. (2017). Urbanization, democracy, bureaucratic quality, and environmental degradation. Journal of Policy Modeling, 39(6), 1035-1051. https://doi.org/https://doi.org/10.1016/j.jpolmod.2017.04.006

Boehmer-Christiansen, S. (2002). The geo-politics of sustainable development: bureaucracies and politicians in search of the holy grail. Geoforum, 33(3), 351-365.

https://doi.org/https://doi.org/10.1016/S0016-7185(02)00018-0 
128 Jurnal Administrare: Jurnal Pemikiran Ilmiah dan Pendidikan Administrasi Perkantoran Vol. 5, No. 2, Juli - Desember 2018, Hal 123-128

Colenbrander, D., \& Bavinck, M. (2017). Exploring the role of bureaucracy in the production of coastal risks, City of Cape Town, South Africa. Ocean \& Coastal Management, 150, 3550. https://doi.org/https://doi.org/10.1016/j.ocecoaman.2016.11.012

Creswell, J. w. (2014). Research Design: qualitative, quantitative, and Mix Methods Approaches (Fourth). Los Angeles, USA: Sage Publications.

Lane, D., \& Ross, C. (1994). Limitations of party control: The government bureaucracy in the USSR. Communist and Post-Communist Studies, 27(1), 19-38. https://doi.org/https://doi.org/10.1016/0967-067X(94)90028-0

Moleong, L. J. (2007). Qualitative research methodology. Bandung, PT Remaja Rosdakarya, Year.

Ongolo, S. (2015). On the banality of forest governance fragmentation: Exploring "“gecko politics"' as a bureaucratic behaviour in limited statehood. Forest Policy and Economics, 53, 12-20. https://doi.org/https://doi.org/10.1016/j.forpol.2015.01.005

Osipian, A. L. (2017). University autonomy in Ukraine: Higher education corruption and the state. Communist and Post-Communist Studies, 50(3), 233-243. https://doi.org/https://doi.org/10.1016/j.postcomstud.2017.06.004

Schlosser, K. (2017). Education and intimate war of position: The National Security League's Committee on Patriotism through Education, 1917-1919. Political Geography, 60, 66-75. https://doi.org/https://doi.org/10.1016/j.polgeo.2017.04.008

Yanguas, P., \& Hulme, D. (2015). Barriers to Political Analysis in Aid Bureaucracies: From Principle to Practice in DFID and the World Bank. World Development, 74, 209-219. https://doi.org/https://doi.org/10.1016/j.worlddev.2015.05.009

Zakharova, E., Liga, M., \& Sergeev, D. (2015). Constructing Philosophy of Environmental Education in Contemporary Russia. Procedia - Social and Behavioral Sciences, 214, 1181-1185. https://doi.org/https://doi.org/10.1016/j.sbspro.2015.11.739 